\title{
Feminism Aspects of Main Characters in the Selena Novel of Tere Liye's Work
}

\author{
Sunnasyiah $^{1 *}$, Dessy Wardiah ${ }^{1}$, Yessi Fitriani ${ }^{1}$ \\ ${ }^{1}$ Universitas PGRI Palembang \\ *Corresponding author. Email: sunn181070@gmail.com
}

\begin{abstract}
The aim of this study was to identify and describe the feminist aspects of the main character in Selena of Tere Liye's novel. The formulation of the problem in this research was how the feminist aspects of the main character (Selena) in Tere Liye's novel. This study used a qualitative descriptive research method, the data source in this study was the novel Selena of Tere Liye's works, while the data obtained in this study were contained words, sentences and discourses in the novel Selena of Tere Liye's works. The data collection analysis technique in this study used the documentation techniques. The data analysis techniques in this research were reading novels, collecting data, classifying data, identifying data according to the theory of feminism, made discussions and concluded the results of the analysis into research findings. The results obtained in the study were socio-cultural aspects, educational aspects, economic aspects, political aspects contained in Selenaof Tere Liye's works using feminism studies. The novel tells the portrait of public life.
\end{abstract}

Keywords: Feminism, Main Character, and Novel.

\section{INTRODUCTION}

In the current development of novel in Indonesia, there have been many literary works written by women writers, such as Fira Basuki, Asma Nadia, NH Dini, Ayu Utami, Helvy Tiana Rossa, Dewi Lestari, Habiburrahman El Shirazy, and so on. This phenomenon shows that today men are no longer dominant in producing quality literary works. This is proven by the large number of women writers who enjoy their work and not a few of their works are made into films. One of the problems in society that writers often raise in their work is the problem of women. Many literary works such as novels tell about women with all their problems. One of them is the novel Selena by Tere Liye.

In literature, all human behavior and characters have different story characters, both female and male characters. This is in line with differences in opinion between men and women, so that there is oppression of women. Therefore, in a literary work there are also those who tell about it. The women's movement is to defend their right to move or try to be equal to men or so-called feminism.

This is in line with Sofia's opinion quoted by [1]. "Defining feminism as an ideological critique of a perspective that ignores the problem of inequality and injustice in assigning social roles and identities based on gender differences." Based on the above opinion, women's injustice in a literary work needs to be examined as feminism. Feminism has questioned the rights and interests of women, which so far have been unfair. According to "Women in the view of feminism have their own activities and initiatives to fight for these rights and interests in the movement to claim their rights as human beings in full." According to this opinion, feminism literary research can be studied from various streams of feminism.

Talking about feminism means talking about ideology, not discourse. The essence of feminism is resistance, anti, and free from oppression, domination, hegemony, injustice, and violence. The peculiarity of feminism is against oppression. This resistance was pursued in various ways or actions. Because against oppression, this resistance must be preceded by critical awareness and self-organization. With her eyes, heart and actions, namely that she realizes, sees, experiences oppression that occurs when women question them, sue and take action to change these conditions.

Feminism thus favors women, those who are oppressed, discriminated against, exploited and neglected. Feminism exposes experiences of oppression as women, questions power relations that occur in women. Feminism is fighting for the humanity of women, fighting for women as free human beings towards the arrangement of new social relations in 
which women and men are the whole subject in making decisions in the allocation of power and its resources. This change does not come automatically but must be fought for.

The researcher's reason for studying feminism is because in this era of emancipation, the dignity of a woman has the same as that of men. The burden and responsibility of a woman is greater than that of men. Besides that, the novel Selena by Tere Liye is very interesting for researchers because it contains feminism. Women are seen as fat figures, there are many perceptions circulating in society about women themselves which cause women to be increasingly marginalized.

Another reason the researcher chose Tere Liye's novel Selena is in terms of feminist aspects tells the figure of Selena, a math teacher in the Earth Clan. The story begins when Selena was 15 years old, was an orphan because her father died, and then followed her mother, living in poverty and living in the Sixth Sabit District. After his mother's forgiveness, Selena is given a will by Togra, the head of the Sixth Sabit District who previously entrusted her mother to Selena. According to his mother's will, he moved to the city of Tishri, to live with his uncle named Uncle Raf. Poor and penniless, his neighbors kindly raised money for expenses to the capital. So Selena left, headed for the Tishri City Central Station armed with the address listed in the will. After meeting his uncle, he was allowed to stay, but he did not stay free, as a contribution because he was already living with his mother's family, so his uncle told him to work and join the team of workers his uncle had hired, working on the construction of the subway tunnel. Actually, her aunt really didn't agree with Selena to work hard like that, while her talkative uncle who wanted to compromise was that her aunt and uncle continued to fight. Selena reassures her Aunt that she will be fine, and learns many new things at the construction site.

Through Selena's book, we are shown in more detail how life in the Moon Clan especially about the High Level Shadow Academy from Miss Selena's point of view. Surely the background of the Moon Clan is already familiar because it has started to be told in the middle of the first book on Earth. This time, we will look at a Flash back from the teachers of the three of them, Miss Selena, starting when he was born in a remote place in the Moon Clan. He was not gifted at mastering the combat techniques that the Moon Clan normally possessed. One of its advantages is just a super sharp observation.

Even so, Selena didn't give up. He still aspires to one day join High Level Shadow Academy, the best school in the entire moon clan,in order to become a soldier. Just as he started to feel hopeless, suddenly a figure namedTamus before him, the same figure appeared in
Raib's mirror in the first book. He promises to make Selena have super powers so she can take up studies in her dream place. In return, Selena had to serve him and obey his orders. He was assisted by two students named Mata and Tazk. They eventually become friends and very close to each other. In the midst of her school life, Selena often gets missions from Tamus, who she always succeeds in completing. He also realizes that there is a mysterious clan that has an heirloom that Tamus is eyeing.

The novel Selena by Tere Liye providing inspiration for researchers to find out more and at the same time adding insight into knowledge about the life picture of the characters in Tere Liye's Selena novel which tells about the life of a woman from an educational perspective. But on the other hand, there are problems that often adorn his personal life, namely the struggle to gain success in his life that never knows giving up and giving up. Various problems and conflicts in life that befall this character and the efforts he does in navigating through life. This shows that aspects of feminism are very appropriate to be applied in this research. This research is focused on the study of aspects of feminism which include: socio-cultural aspects, economic aspects, educational aspects, political aspects, and legal aspects contained in the novel Selena by Tere Liye. The formulation of the problem in this study is how the aspects of feminism in Is the novel Selena by Tere Liye in terms of socio-cultural aspects, economic aspects, educational aspects, political aspects, and legal aspects?

\section{METHODS}

Satori [2] explains that the method is one of the methods used by researchers in an effort to solve the problem being studied. Mahsun [3] further argues that in the course of the research, a detailed description of how to carry out the research, including the scope of the description. Meanwhile, Moleong [4] explains that the descriptive data collected is in the form of words, pictures, and not numbers. Thus, the research report contains data quotations to provide an overview of the presentation of the research report. Furthermore, Surakhmad [5] states that the method is the main way to achieve goals, for example, to test a series of hypotheses using certain tools. This research is descriptive research. Meanwhile, Sukmadinata stated that descriptive research is a form of research aimed at describing existing phenomena, both natural phenomena and manmade phenomena. These phenomena can be in the form of forms, activities, characteristics, changes, relationships, similarities and differences between one phenomenon and another.

Descriptive method is a method that discusses several possibilities to solve a problem, one of which is the feminism aspect in Tere Liye's novel Selena, with data in the form of quotations that are obtained that need 
to be described or presented as they are so that in the end the aspects of feminism in the novel will be known Selena by Tere Liye which includes: five aspects namely socio-cultural aspects, educational aspects, economic aspects, political aspects and legal aspects.

As for the source of data in this study, we used a novel entitled Selena by Tere Liye. The data in this study are data in the form of words, sentences, and discourses contained in the novel Selena by Tere Liye, with the data in the form of quotations obtained that need to be described or explained as they are so that in the end the aspects of feminism will be known. Selena's novel by Tere Liye which includes: five aspects namely socio-cultural aspects, educational aspects, economic aspects, political aspects and legal aspects. Selena's novel by Tere Liye was published in 2020 with a total of 368 pages, $20 \mathrm{~cm}$ thick.

The main documentation technique used in this research is Selena's novel by Tere Liye which includes: five aspects namely socio-cultural aspects, educational aspects, economic aspects, political aspects and legal aspects, thus requiring writers to be able to collect various documents such as citations, notes, books, files, articles and so on. This is done by researchers so that the results of this study can be justified because they are supported by relevant previous theories and studies. The data analysis technique used in this research is the content analysis technique, namely analyzing the contents of the novel in the form of a collection of sentences and paragraphs. Then the data that has been obtained from the novel is analyzed and described. The steps taken are as follows.

1. Read over and over throughout the whole novel to understand its contents as a whole.

2. Collecting data, in the form of sentences contained in novels that contain aspects of feminism.

3. Grouping data into several aspects, namely sociocultural, economic aspects, educational aspects, political aspects, and legal aspects in the novel Selena by Tere Liye.

4. The collected data were interpreted in accordance with the theory of feminism.

5. Discussion of the results of data analysis that has been obtained.

6. Conclude the results of the analysis into findings.

\section{RESULTS AND DISCUSSION}

Feminism is an understanding to make women aware of the low position of women in society and the desire to improve or change this situation [6]. Feminism in literary research is considered as an awareness movement towards ignoring the existence and exploration of women in society as reflected in literary works [7]. Then empirically, women are also created stereotypically as being gentle, beautiful, emotional and motherly, while men are considered as being strong, rational, male and mighty [8].

Inspired by the writing of St in his article entitled Looking for a Critical Education Profile, KAPAL Perempuan tries to develop aspects of this change whose naming is almost similar or even the same as that introduced by St Sunardi but with a different description because it is contextualized with KAPAL's experience during this. Feminists can be said to be successful if important aspects of the individual change. Based on the thoughts in feminism described above, it can be seen that there are several demands fought by feminists which include socio-cultural aspects, educational aspects, economic aspects, political aspects, and legal aspects [6].

\section{Implementation Socio-Cultural Aspects}

Feminism in this aspect is a movement carried out by women in an effort to eliminate the point of view that has cornered women. The socio-cultural aspects of feminism in Tere Liye's novel Selena are shown in the following quote.

"My father was buried in the Sixth Sabit District, a funeral for low-level residents. We don't have the money to send my father to the modern Tishri City funeral system. " .

Based on the quote above, it is explained that the socio-cultural aspect on the feminist aspects of Tere Liye's novel Selena, the public relations shown in the quote from Selena's father are buried in the Sixth Sickle District where the burial of the lower strata of the population. If you have money Selena wants her father to be buried in the city of Tishri which is even better.

\section{Educational Aspects}

The study of educational aspects on aspects of feminism in Tere Liye's novel Selena is shown in the following quote.

"Not even fifteen years old! You're not rational, Raf. He should be sent to school, not work." .

Based on the quotation above, it is explained that the educational aspect on the aspects of feminism in Tere Liye's novel Selena, it is shown that she is not yet fifteen years old to work with. Children of that age should get education, not work.

\section{Economic Aspects}

The economic aspects of feminism in Tere Liye's novel Selena are shown in the following quote. 
"Our family is poor, unable to take my father to the latest medical center in Tishri city. After struggling for months, my father died. My father was buried in the Sixth Sabit District, a cemetery for the lower strata of the population. We don't have the money to send Father to the modern Tishri city funeral system. " .

Based on the quotation above, it is explained that the economic aspect on the feminist aspects of the novel Selena by Tere Liye, it is shown in the quotation that our family is poor, unable to bring my father to the mukhtahir medical center of Tishri city. We don't have the money to send father to the modern burial system of the city of Tishri.

\section{Political Aspects}

The political aspects that exist in the aspects of feminism in Tere Liye's novel Selena can be seen in the following quote.

"But at least, your uncle is fair. He gave each worker a proper salary, as well as rations of this food. Everything is guaranteed. That's why, even though they often hear his scolding, the workers are still loyal to him. " .

Based on the quotation above, it is explained that there are political aspects on the aspects of feminism in Tere Liye's novel Selena, it is shown the way Selena's uncle takes action against his workers. Even though they often grumble, the workers are always given proper wages and are given food rations, so that the workers remain loyal to them.

\section{Legal Aspects}

Feminism in the legal aspect is a movement of women who defend the truth regardless, whether friends or foes should be fair. In the legal aspect of feminism, she has the full right to defend the truth.

The legal aspects that exist in the aspects of feminism in Tere Liye's Selena can be seen in the following quote.

"I don't want to know, the work progress must be according to the City Council's request. Once a post fails, I myself will beat the workers so that they cannot stand up, and you are the foremen, I will curricum to the city prison" .

Based on the quotation above, it is explained that the legal aspects exist on the feminist aspects of Tere Liye's novel Selena, it is shown in the quote I don't want to know, the progress of the work must be at the request of the City Council. Once a post fails, I myself will beat the workers so that they cannot stand up, and you are the foremen, I will curricum to the city prison. Based on the findings of an analysis of the aspects of feminism in Tere Liye's Selena novel, it is known that there are several aspects, namely: socio-cultural aspects, educational aspects, economic aspects, political aspects, and legal aspects.

\section{Discussion of Socio-Cultural Aspects.}

Socio-cultural aspects are related to the society that is built and lives in a society. In the social sphere, women's rights are very limited. Women are considered to be second only to men, women are considered weak, subtle, passive, dependent, emotional, not independent, motherly, patient and the like so that women are considered to be working in the domestic sector [9]. Feminism in this aspect is a movement carried out by women in an effort to eliminate the point of view that has cornered women.

\section{Discussion of Educational Aspects}

Education is a process of changing attitudes and behavior either formally or informally. The view of society, women are emotional, irrational, and this view results in conditions that are conditioned not to appear as leaders. Discrimination against women appears in all forms which differ from one place to another. In Java and Sunda there is an assumption that women don't have to go to high school, because they end up going to the kitchen too. In addition, in households with mediocre economies, discriminatory family decisions are still heard, namely prioritizing the education of boys over girls [10].

\section{Discussion of Economic Aspects}

Career women are interesting things to talk about because most of the employment opportunities are closed to women. Even if she was given the opportunity to earn a living, the wages she received were much lower than the wages received by men. This is due to the society's assumption that men are the breadwinners so that they are responsible for fulfilling the needs of their wives and children while women are only seen as complementary. People also think that it is already an obligation for women to manage household affairs, such as cleaning the house, washing clothes, cooking, caring for children and the obligation to serve husbands [11].

\section{Discussion of Political Aspects}

Political struggle in a feminist context is not the same as political understanding in general. Political struggle for feminists does not only concern public political life, which must involve various groups and be massive. Opening up his experience as an oppressed person in the family and in society can be considered as political. So far, the problem has always been considered casuistic, meaning that it is only experienced by certain people. Even though this assumption is not true, it has raised awareness that the problems experienced by one person are still problems and cannot be just eliminated. 


\section{Discussion of Legal Aspects}

The world of law which for centuries has been ruled and controlled by women who have absolutely no experience. Men who generally refuse to let women shift or take over their positions always hinder the struggle of feminists [12]. Seeing their difficult position, feminists realized that the only way to be able to enter the world of law is through education. They hope that through education, their knowledge will become broad and they can find out the intricacies of various fields, including the field of law .

Based on theoretical studies, Semi [13] suggests that basically literary works display a series of events. This event was brought to life by characters, each of whom had their own role as outlined in writing. Literary work is part of culture, its birth in the midst of society is not immune from social and cultural influences. This influence is reciprocal, meaning that literature can influence and be influenced by society. Martilopa [14], with the title, "Personality Structure and Emotional Classification of the Main Character in Eka Kurniawan's Lelaki Harimau Novel, Literary Psychology Study." The results of this study concluded that the classification of emotions, it can be concluded that there are four characters who are the target objects of the emotional classification in the novel, namely Margio, Komar Bin Syueb, Nuraeni, and Maharani. Margio's emotional classification includes guilt, self-punishment, shame, sadness, hatred, and love. The emotional classification of Komar Bin Syueb's character consists of guilt, shame, hatred and love.

\section{CONCLUSION}

Based on the research findings, it can be concluded that the aspects of feminism in Tere Liye's novel Selena have several aspects, namely socio-cultural aspects, educational aspects, economic aspects, political aspects and legal aspects.

1. In the socio-cultural aspects of the novel Selena by Tere Liye, there are many things that can be obtained, including when Selena's parents died, they were buried in a low-level cemetery. Selena when heading to Tishri city saw that there were differences in the strata of the population which were divided into two groups, namely the rich and the poor.

2. In an educational aspect, this novel tells about Selena, who has a high passion for success, where Selena is able to become the best student in the land of the Moon Clan who is accepted into the High Level Shadow Academy and one of the best graduate students.
3. In the economic aspect, this novel tells the story of Selena as a poor person and after the death of her parents, her parents entrusted her to her uncle and sent Selena to work.

4. In a political aspect, this novel tells the story of Aq who treats his workers well and provides him with a decent salary and sufficient food, so that his workers are obedient and loyal.

In the legal aspect, this novel tells of several incidents of law violations committed by students in the land of the Moon Clan who are studying at the High Level Shadow Academy.

\section{REFERENCES}

[1] Sofia, A. (2014). Feminist Literary Criticism. Yogyakarta: Citra Pustaka Yogyakarta.

[2] Satori, D. et al. (2013). Qualitative Research Methodology. Bandung: Alfabeta.

[3] Mahsun. (2017). Language Research Methods. Jakarta: Raja Grafindo Persada.

[4] Moleong, L. (2012). Qualitative Research Methodology. Bandung: Rosdakarya.

[5] Surakhmad. (2016). Research Methods. Bandung: Alfabeta.

[6] Asmaeny. (2017). The Study of Feminism. Jakarta: Raja Grafindo Persada.

[7] Sugihastuti. (2010). Gender and Women's Inferiority. Yogyakarta: Student Library.

[8] Sunardi, ST. (2012). Looking for Critical Education Profiles, KAPAL Perempuan. Article, Bandung: UPI.

[9] Nugroho. (2013). Feminism. Jakarta: Rineka Cipta.

[10] Darma. (2013). Aspects of Feminism. Jakarta: Rineka Cipta.

[11] Wiyatmi. (2012). Feminist Literary Criticism: Theory and Its Application in Indonesian Literature, Yogyakarta: Waves.

[12] Djananegara. (2013). Theory of Feminism in Life. Jakarta: Raja Grafindo Persada.

[13] Semi, A. (2013). Literary Criticism. Bandung: Space.

[14] Martilopa, N., \& Ardiansyah, A. (2020, May). Struktur kepribadian dan klasifikasi emosi tokoh utama dalam novel lelaki harimau karya eka kurniawan kajian psikologi sastra. In Prosiding Seminar Nasional Program Pascasarjana Universitas PGRI Palembang. 